\title{
Decreased Capacity for RNA Synthesis in vitro in a Membrane Fraction from Micrococcus radiodurans Irradiated by Ionizing Radiations
}

\section{Sir:}

In our recent studies on the mechanism for radiation resistance of $M$. radiodurans, ${ }^{1-31}$ the following results have been obtained: (1) remarkable radiation resistance of this vegetative bacterium is mainly due to the efficient capacity to repair DNA lesions including double-strand scissions, (2) the inhibition of protein and RNA synthesis during the postirradiation incubation resulted in the blocking of the repair of radiation-induced strand breaks in DNA, that is, DNA repair requires de novo protein and/or RNA synthesis, (3) the cellular sensitivity to ionizing radiations increased by the postirradiation treatment with either of actinomycin D, chloramphenicol and tetracycline, and (4) inhibition of protein and RNA synthesis in $M$. radiodurans cells increased as much as that of DNA synthesis with increasing radiation doses. Based on these results, it is assumed that inhibition of protein and RNA synthesis is of primary significance for the cell death in a radioresistant bacterium $M$. radiodurans caused by high doses of ionizing radiations.

In order to prove this view, the experiment using the cell-free system has been undertaken. The membrane fraction was prepared from unirradiated and irradiated cells of $M$.

l) S. Kitayama and A. Matsuyama, Biochem. Biophys. Res. Commun., 33, 418 (1968).

2) A. Matsuyama and S. Kitayama, Abstracts of 4th International Congress of Radiation Research, Evian, France, pp. 140 (1970).

3) S. Kitayama and A. Matsuyama, Agr. Biol. Chem., 34, 1346 (1970). radiodurans by lysing protoplasts with Triton $\mathrm{X}-100$ according to the partial modification of Nisman's method. ") Log-phase cells suspended in TM-buffer (Tris-HCl $10^{-2} \mathrm{M}, \mathrm{MgCl}_{2}$ $10^{-3} \mathrm{M}, \mathrm{pH} 7.6$ ) were irradiated by $4.5 \times 10^{4}$ rads and $8.5 \times 10^{5}$ rads of ${ }^{60} \mathrm{Co}$ gamma rays. They were then washed with TMS-buffer (Tris- $\mathrm{HCl} 10^{-1} \mathrm{M}, \mathrm{MgCl}_{2} 1.5 \times 10^{-2} \mathrm{M}$, sucrose $\left.5 \times 10^{-1} \mathrm{M}, \mathrm{pH} 7.6\right)$ two times and incubated with lysozyme $(2 \mathrm{mg} / \mathrm{ml})$ in the presence of EDTA $\left(2 \times 10^{-3} \mathrm{M}\right)$ in TMS-buffer at $37^{\circ} \mathrm{C}$ for $30 \mathrm{~min}$. After washing the protoplasts twice with cold TMS-buffer, Triton X-100 was added at a final concentration of $0.5 \%$ and the mixture was then chilled in an ice bath for $30 \mathrm{~min}$. After lysing, the membrane fraction was collected by centrifugation at $14,000 \times \mathrm{g}$ for $20 \mathrm{~min}$, washed twice and resuspended in TMS-buffer. The reaction mixtures used in this experiment are shown in Table I. Incorporation of ${ }^{14} \mathrm{C}$-ATP into the acid-insoluble fraction was regarded as a measure of RNA synthesis by the membrane fraction.

The results obtained in this experiment revealed that the activity of RNA synthesis in this bacterium is profoundly inhibited at a very high dose of $8.5 \times 10^{5} \mathrm{rads}$, while it is only slightly inhibited by $4.5 \times 10^{4}$ rads, as can be seen in Table I. This fact means that the inhibition of RNA synthesis would be due to the radiation damages in its synthetic

4) B. Nisman, "Methods in Enzymology," Vol. XII, Nucleic Acids, Part B, ed. by L. Grossman and K. Moldave, Academic Press, New York, 1968, pp. 794. 
TABLE I. EFFect of Gamma IRRAdiation on RNA Synthesis in witro

\begin{tabular}{|c|c|c|c|}
\hline Enzyme fraction & $\begin{array}{c}\text { Radiation dose } \\
\text { before lysis } \\
\left(\times 10^{5} \text { rads }\right)\end{array}$ & Condition of incubation & $\begin{array}{l}\text { cpm } 0.5 \mathrm{mg} \\
\text { Protein of the } \\
\text { enzyme fraction }\end{array}$ \\
\hline Membrane & - & No incubation & 120 \\
\hline " & - & Complete & 2861 \\
\hline$"$ & - & Complete minus GTP, CTP and UTP & 110 \\
\hline$"$ & - & Complete plus DNase $(5 \mu \mathrm{g} / \mathrm{ml})$ & 100 \\
\hline Supernatant & - & Complete & 65 \\
\hline Membrane & 0.45 & Complete & $2 ! 65$ \\
\hline Supernatant & , & $"$ & 78 \\
\hline Membrane & 8.5 & " & 714 \\
\hline Supernatant & " & " & 115 \\
\hline
\end{tabular}

The complete reaction mixture contained the followings in $\mu$ moles/ml: Tris- $\mathrm{HCl}, \quad 50 ; \quad \mathrm{MgCl}_{2}, 0.5 ; \beta-$ mercaptoethanol, 1.5; ATP, GTP, CTP and UTP, 0.4 each; ${ }^{14} \mathrm{C}-\mathrm{ATP}, 0.2 \mu \mathrm{Ci}$. The reaction mixture contained $0.8 \sim 1.2 \mathrm{mg}$ protein of the enzyme fraction. Incubation was carried out at $37 \mathrm{C}$ for $20 \mathrm{~min}$.

system, but not to secondary effects of radiation damages on permeability, active transport systems or energy generating systems. As previously reported, " the colony survival was about 1 per cent for $8.5<10^{5}$ rads and 100 per cent for $4.510^{4}$ rads. Thus, the above view on the primary importance of the inhibition of the RNA synthesis for the cell death in $M$. radiodurans was supported by the present in vitro experiment. Since the inhibition of the DNA repair after $8.5 \times 10^{5}$ rads was much greater than that after $4.5 \times 10^{4}$ rads, ${ }^{3 \prime}$ it appears that the RNA synthesis after irradiation may play an important role in the repair of DNA lesions caused by radiation in this radioresistant bacterium.

Evidence for the inhibition of protein synthesis by irradiation in a cell-free system prepared from $M$. radiodurans has not yet been obtained. However, in the preliminary trial the serious inhibition of this activity in cellfree extracts of $E$. coli was found after relatively high doses of gamma rays.

These findings mentioned above allow us to maintain the view that the inhibition of protein and RNA synthesis may play a primarily important role in cell death in $M$. radiodurans caused by ionizing radiations, perhaps associating with the arrest of DNA-repair processes to rejoin double-strand scissions and inhibition of DNA replication, in other words, de novo protein and RNA synthesis is required during postirradiation incubation to repair double-strand scissions in DNA.

\footnotetext{
Acknowledgements. The authors wish to express their thanks to Miss Y. Kojima and Miss H. Koyama for their technical assistance. This work was partly supported by research grants from the Ministry of Education and from the Science and Technology Agency.
}

Shigeru KitaYama Akira MatsuYama

Radiobiology Laboratory

Institute of Physical and Chemical Research

Yamato-machi, Saitama Prefecture, 351

Japan

Received July 16, 1970 